I N T ER N ATIONAL MONETARY FUND

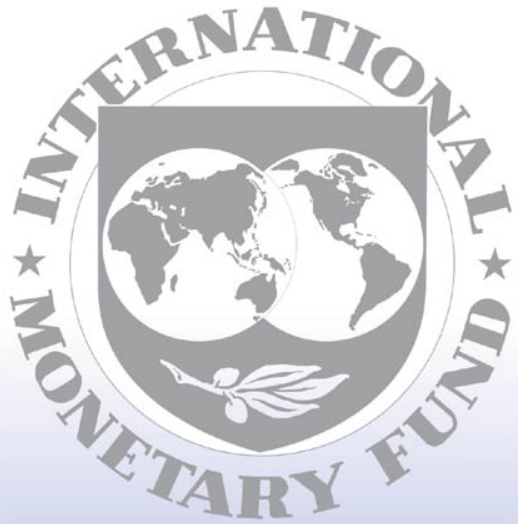

Staff

Country

Reports 


\section{France: Report on the Observance of Standards and Codes-Transparency in Monetary and Financial Policies: An Update}

This report updates the developments in fiscal transparency since the September 2000 "Observance of Standards and Codes-France" (available on the IMF website at http//www.imf.org/external/np/rosc/fra/trans.htm/ ). It has been prepared by a staff team and does not necessarily reflect the views of the government of France or the Executive Directors of the IMF.

The policy of publication of staff reports and other documents allows for the deletion of market-sensitive information.

To assist the IMF in evaluating the publication policy, reader comments are invited and may be sent by e-mail to Publicationpolicv@imf.org.

Copies of this report are available to the public from

International Monetary Fund - Publication Services

$70019^{\text {th }}$ Street, N.W. - Washington, D.C. 20431

Telephone: (202) 623-7430 - Telefax: (202) 623-7201

E-mail: publications@imf.org Internet: http://www.imf.org

Price: $\$ 15.00$ a copy

International Monetary Fund

Washington, D.C. 


\section{REPORT ON THE OBSERVANCE OF STANDARDS AND CODES FRANCE: TRANSPARENCY IN MONETARY AND FINANCIAL POLICIES-AN UPDATE OCTOBER 2001}

This note providesfactual information on developments in transparency in monetary and financial policies since the October 2000 Report on the Observance of Standards and Codes, It should be read in conjunction with the original report. ${ }^{1}$

The framework for supervision and regulation applicable to a specific group of mutual insurance firms (mutuelles de 1945\} has been modified by adjusting the law governing these institutions to comply with European regulations concerning insurance. Once implementing regulations are in effect, these insurance companies will need to meet the same solvency rules as provided in the Insurance Code, thus clarifying that aspect of their regulation. They will, however, remain subject to supervision by the CCMIP (Commission de contrôle des mutuelles et des institutions de prévoyance), rather than by the regular insurance supervisor (CCA).

\footnotetext{
${ }^{1}$ The original report was issued to the Executive Board as SM/00/236 and is on the IMF website as http:/www.imf.org/external/np/rosc/fra/trans.htm/.
} 